\title{
Deployment of Armed Forces During the Coronavirus Crisis: Compliance with the OSCE Code of Conduct?
}

\author{
Alexandre Lambert, Filip Ejdus, Thomas Schmidt"
}

\begin{abstract}
The aim of this paper is to assess whether the deployment of European armed forces during the coronavirus crisis has been in compliance with the OSCE Code of Conduct on PoliticoMilitary Aspects of Security and other relevant OSCE documents. We show that most of the measures taken by OSCE participating States in response to the COVID-19 pandemic thus far have complied with OSCE norms and commitments. Nonetheless, weak points are identified, particularly in relation to the provision of a clear definition of the role and mission of armed and security forces and safeguards related to the principles of necessity, proportionality, and non-discrimination in the context of measures taken to address public emergencies. There have also been a few cases of derogation from obligations related to basic human rights and fundamental freedoms. We offer policy recommendations for strengthening future compliance with OSCE norms and commitments on the domestic use of armed forces in support of civilian authorities in emergency situations.
\end{abstract}

\section{Keywords}

coronavirus, OSCE, Code of Conduct on Politico-Military Aspects of Security, armed forces

To cite this publication: Alexandre Lambert, Filip Ejdus, Thomas Schmidt, Deployment of Armed Forces During the Coronavirus Crisis: Compliance with the OSCE Code of Conduct?, OSCE Insights 5 (Baden-Baden: Nomos, 2020), at: https://10.5771/9783748922339-04

\section{Introduction $^{1}$}

Toward the end of 2019, an atypical viral pneumonia appeared in the province of Wuhan in the People's Republic of China. By early 2020, the disease had been identified as COVID-19, caused by the coronavirus SARS-CoV-2. On 30 January, the Director-General of the World Health Organization (WHO) declared the outbreak of the disease a public health emergency of international concern. Soon after, the virus quickly spread across the world. To curb this unprecedented health emergency, which came to be known as the coronavirus crisis, most OSCE partic-

* Prof. Dr Alexandre Lambert Geneva Institute of Geopolitical Studies lambert@geopolitics-geneva.ch

Assoc. Prof. Dr Filip Ejdus University of Belgrade filip.ejdus@fpn.bg.ac.rs

Colonel Thomas Schmidt

Permanent Mission of Switzerland to the OSCE, the United Nations and other International Organizations in Vienna thomas.schmidt@eda.admin.ch 
ipating States introduced some form of emergency regime, including the use of armed forces.

As large and well-organized bodies with substantial infrastructure and human and material resources, modern militaries are expected to engage in contingencies like this and to support civilian authorities in times of crisis. While doing so, however, they must comply not only with the constitutional frameworks in which they operate but also with international norms on the use of force, including those originating from the OSCE. As a security organization, the OSCE does not deal directly with health and medical issues. Nevertheless, the 1994 OSCE Code of Conduct on Politico-Military Aspects of Security (the Code) provides normative guidance for the deployment of armed forces in public health emergencies such as the coronavirus crisis. ${ }^{2}$ This is especially so given the Code's relevance to both the politico-military dimension and the human dimension of security. ${ }^{3}$

The key question addressed in this paper is how European armed forces have been used in the coronavirus crisis and whether this use has complied with OSCE norms and commitments. We first outline the normative provisions of the Code and other OSCE documents that can be seen to apply to the domestic use of force in public emergencies, including health emergencies such as the coronavirus crisis. We then offer an analysis of the different ways in which states have made use of their military forces in the crisis and identify the most significant challenges with respect to compliance with the relevant OSCE norms.
We draw on official documents of the OSCE and participating States, including the official websites of ministries of defence and armed forces, country reports to the European Organisation of Military Associations and Trade Unions, academic publications, and news reports. Our analysis covers the period from the recognition of COVID-19 as a public health emergency in January 2020 to early September 2020, when the first peak of the pandemic had subsided in most European countries and measures responding to the second wave had not yet been introduced. In terms of the countries covered, the analysis encompasses European OSCE participating States. Our analysis shows that while there are clear risks associated with both domestic deployments and states of emergency, the countries examined have generally complied with OSCE norms, although with a few notable exceptions. In conclusion, we draw lessons learned from the coronavirus crisis and offer policy recommendations.

\section{Relevant OSCE norms}

OSCE documents, which are politically binding, contain several provisions that are relevant to the use of armed forces during the coronavirus crisis. A first group of provisions contained in documents relevant to the OSCE's third, human, dimension of security relates to public emergencies in general. The 1991 Moscow Document on the Human Dimension of Security ${ }^{4}(\mathbb{2} 28.10)$ requires participating States to notify the CSCE (forerunner of the OSCE) when a state of 
emergency is declared or lifted and to give notice of any future derogations from their international human rights obligations due to a state of emergency. ${ }^{5}$ This was further elaborated in the 1992 concluding document of the Helsinki Summit, ${ }^{6}$ which set out that the Office for Democratic Institutions and Human Rights (ODIHR) would serve as the OSCE's clearinghouse for information on states of public emergency. Paragraphs 24 and 25 of the 1990 Copenhagen Document are also relevant to potential derogations from obligations related to basic human rights and fundamental freedoms during public emergencies. ${ }^{7}$ They clearly prohibit the abuse and arbitrary application of restrictions on human rights and fundamental freedoms and stipulate that legitimate restrictions and exceptions must observe the principle of proportionality ( $\$ 24)$. This provision reminds participating States that a certain number of fundamental human rights are not open to derogation clauses and thus cannot be restricted, even in times of emergency (or war).

Finally, $\mathbb{} 25$ of the Copenhagen Document includes specific clauses that set out the principles of publicity (25.2), necessity (25.3), and non-discrimination (25.4) in the context of a state of emergency. Regarding necessity, it provides that "measures derogating from obligations will be limited to the extent strictly required by the exigencies of the situation". Concerning non-discrimination, $\mathbb{} 25$ states that "such measures will not discriminate solely on the grounds of race, colour, sex, language, religion, social origin or of belonging to a minority". ${ }^{8}$
A second group of provisions relevant to the coronavirus crisis in OSCE documents relates to the use of force for internal security purposes. As mentioned above, the Code is the OSCE's key source of normative provisions on the use of armed forces. It includes a group of complementary provisions concerning the deployment of armed and security forces for internal security missions, applicable, for example, to the enforcement of public emergencies. They stipulate that such missions must comply with international human rights standards, including standards related to the basic rights and fundamental freedoms of armed forces personnel, thus supplementing the human dimension norms mentioned above.

The paragraphs of the Code that are most relevant to the coronavirus crisis are $\$ 21$, which deals with the importance of the constitutional framework for democratic control, $\mathbb{\$} 34$, which concerns respect for international law, and $\$ \$ \$ 36-37$, which contain provisions relating to the assignment of armed forces for internal security missions, including the principle of proportionality in the (potential) use of force mentioned above. Due to their significance, these paragraphs are provided here (see text box). 


\section{OSCE Code of Conduct provisions most relevant} to the coronavirus crisis

$\$ 21$. Each participating State will at all times provide for and maintain effective guidance to and control of its military, paramilitary and security forces by constitutionally established authorities vested with democratic legitimacy. Each participating State will provide controls to ensure that such authorities fulfil their constitutional and legal responsibilities. They will clearly define the roles and missions of such forces and their obligation to act solely within the constitutional framework.

$\$ 34$. Each participating State will ensure that its armed forces are, in peace and in war, commanded, manned, trained and equipped in ways that are consistent with the provisions of international law $[\ldots]$

$\$ 36$. Each participating State will ensure that any decision to assign its armed forces to internal security missions is arrived at in conformity with constitutional procedures. Such decisions will prescribe the armed forces' missions, ensuring that they will be performed under the effective control of constitutionally established authorities and subject to the rule of law. If recourse to force cannot be avoided in performing internal security missions, each participating State will ensure that its use must be commensurate with the needs for enforcement. The armed forces will take due care to avoid injury to civilians or their property.

$\$ 37$. The participating States will not use armed forces to limit the peaceful and lawful exercise of their human and civil rights by persons as individuals or as representatives of groups nor to deprive them of their national, religious, cultural, linguistic or ethnic identity.

In line with $₫ 25.4$ of the Copenhagen Document regarding the principle of non-discrimination (mentioned above), $\$ 17$ of the Code warns that political tensions may emerge in the case of violations of human rights and fundamental freedoms and that this may endanger peace and security. According to this paragraph, such violations may include "manifestations of aggressive nationalism, racism, chauvinism, xenophobia and antiSemitism".
Finally, the Code contains provisions pertaining specifically to states of emergency, applicable to public health emergencies such as the coronavirus crisis. Participating States deploying armed and security forces in a state of emergency must a) clearly define the roles and missions of armed forces and their obligation to act solely within the relevant constitutional framework $(\$ 21)$; b) provide assurance that the military, paramilitary, and security forces' individual service personnel will be able effectively to exercise their civil rights $(\mathbb{2 3}, \mathbb{3} 2)$; c) protect the political neutrality of the armed forces as an institution $(\$ 23)$; d) safeguard against the accidental or unauthorized use of military means $(\$ 24)$; e) ensure the individual accountability of armed forces personnel under national and international law $(\$ 30)$; and $\mathrm{f}$ ) adhere to the principle that the responsibility of superiors does not exempt subordinates from any of their individual responsibilities $(\mathbb{S} 31)$ - e.g. vis-àvis humanitarian and human rights law.

Regarding the application of the Code, a decision by the OSCE's Forum for Security Co-operation obliges participating States to exchange information on their implementation of its provisions on an annual basis. ${ }^{9}$ This includes voluntary reporting on optional issues. Switzerland voluntarily made use of this opportunity in the information exchange of 2020, including a short chapter called "Measures to Combat the Corona Virus" with the information it provided. It stressed, inter alia, that all national measures taken in response to the pandemic have been in line with the provisions contained in $₫ 24$ and $\$ 25$ of the Copenhagen Document 
and in $\$ 28$ of the Moscow Document. Furthermore, on the occasion of the Annual Discussion on the Implementation of the OSCE Code of Conduct in June 2020, the Permanent Delegation of Switzerland to the OSCE invited all OSCE participating States to use the annual information exchange as an opportunity to share lessons learned and best practices regarding the deployment of armed forces during the coronavirus crisis. ${ }^{10}$

\section{States of emergency and the use of armed forces in the Covid-19 pandemic}

Since the beginning of the coronavirus crisis, more than one-third of OSCE participating States have officially declared a state of public emergency as envisaged by international law, while others introduced other emergency regimes of different intensity or have adopted restrictive measures through legislation and policy. ${ }^{11}$ Twenty-eight participating States have informed ODIHR that they have undertaken emergency measures ${ }^{12}$ in response to the pandemic. The emergency measures undertaken have led to derogations from obligations related to fundamental human rights and freedoms, including freedom of assembly and association, freedom of movement, the right to liberty, the right to a fair trial, the right to respect for private and family life, the right to security, freedom of thought, conscience and religion, the right to property, the right to education, and in some cases freedom of expression and the prohibition of torture and ill treat- ment. Some countries, such as Hungary, introduced an open-ended state of emergency without the time limitations required by the Copenhagen Document. ${ }^{13}$ In addition, emergency measures have posed challenges for democratic oversight and the functioning of parliaments, transparency, privacy (including personal data protection), justice institutions, free and fair elections, and combatting hate crime and discrimination. ${ }^{14}$

Across the OSCE region, participating States have witnessed the militarization of the public sphere - a development that is without recent precedent in most OSCE participating States. High-level politicians have used war metaphors extensively in their political discourse. Their public statements have abounded with references to battles, invisible enemies, and analogies to war and military victories. Although this type of discourse can help to convey urgency, suspend partisanship, foster solidarity, and muster resources, it can also diminish pluralism, undermine democratic procedures, and hinder international solidarity. ${ }^{15}$ This militaristic language also paves the way for both warranted and unwarranted use of armed forces in managing the crisis.

Historically, militaries have played an essential role in curbing pandemics, from the 1918 Spanish flu ${ }^{16}$ to the H1N1 pandemic of 2009.17 With their unrivalled crisis management capabilities, research and development infrastructure, discipline, authority, and command and control, militaries are a natural partner for civilian authorities in public emergencies, including public health emergencies. It is therefore not surprising that military aid 
to civilian authorities has played an essential role across the OSCE region in the coronavirus crisis. In some participating States, this has involved large-scale operations such as Operation Resilience in France, Operation Balmis in Spain, and Operation Restrict in the UK. While in most countries use of armed forces has been "in conformity with constitutional procedures" ( $\$ 36$ of the Code), there have been exceptions. In both Serbia and Albania, for example, parliaments were sidelined, and the executive did not seek their timely approval. ${ }^{18}$

Across the OSCE region, the military has been mobilized for various tasks, which can be grouped into five main categories (see Table 1).

Table 1: Tasks conducted by armed forces of OSCE participating States during the coronavirus crisis

\begin{tabular}{|c|c|c|c|c|}
\hline $\begin{array}{l}\text { Logistics and } \\
\text { Transportation }\end{array}$ & $\begin{array}{l}\text { Medical } \\
\text { Support }\end{array}$ & $\begin{array}{l}\text { Research and } \\
\text { Development }\end{array}$ & $\begin{array}{l}\text { Governance } \\
\text { Support }\end{array}$ & \begin{tabular}{|l|} 
Internal \\
Security
\end{tabular} \\
\hline $\begin{array}{ll}\text { - } & \text { Repatria- } \\
\text { tion of } \\
\text { citizens } \\
\text { - } \\
\text { Humanitar- } \\
\text { ian relief } \\
\text { - Internation- } \\
\text { al assistance } \\
\text { - Transporta- } \\
\text { tion of pa- } \\
\text { tients, med- } \\
\text { ical staff } \\
\text { and PPE }\end{array}$ & $\begin{array}{ll}\text { Disinfec- } \\
\text { tion of pub- } \\
\text { lic areas } \\
\text { - Manufac- } \\
\text { turing of } \\
\text { PPE } \\
\text { - Construc- } \\
\text { tion and } \\
\text { manage- } \\
\text { ment of } \\
\text { field hospi- } \\
\text { tals - Test- } \\
\text { ing and } \\
\text { contact trac- } \\
\text { ing } \\
\text { Provision of } \\
\text { military } \\
\text { medical } \\
\text { staff, PPE, } \\
\text { infrastruc- } \\
\text { ture and } \\
\text { equipment } \\
\text { Morgue } \\
\text { manage- } \\
\text { ment }\end{array}$ & $\begin{array}{ll}\text { - } & \text { Develop- } \\
\text { ment and } \\
\text { testing of } \\
\text { vaccines } \\
\text { - } \\
\text { Production } \\
\text { of disinfec- } \\
\text { tants } \\
\text { - Develop- } \\
\text { ment of } \\
\text { tracing ap- } \\
\text { plications } \\
\text { Production } \\
\text { of PPE }\end{array}$ & $\begin{array}{ll} & \text { Strategic } \\
\text { communi- } \\
\text { cation } \\
\text { Engage- } \\
\text { ment of de- } \\
\text { fence plan- } \\
\text { ners in oth- } \\
\text { er govern- } \\
\text { ment bodies } \\
\text { - Contact } \\
\text { tracing sup- } \\
\text { port }\end{array}$ & $\begin{array}{ll}\text { - } & \text { Border con- } \\
\text { trol } \\
\text { - } \\
\text { Migration } \\
\text { manage- } \\
\text { ment } \\
\text { - Provision of } \\
\text { law and or- } \\
\text { der } \\
\text { - Quarantine } \\
\text { enforce- } \\
\text { ment } \\
\text { - Protection } \\
\text { of hospitals, } \\
\text { retirement } \\
\text { centres, } \\
\text { public en- } \\
\text { terprises, } \\
\text { and critical } \\
\text { infrastruc- } \\
\text { ture }\end{array}$ \\
\hline
\end{tabular}


First, participating States have used their armed forces for logistics and transportation. This includes the repatriation of citizens stranded abroad as tourists or workers and the provision of humanitarian relief inside the country, such as food delivery to those living in poverty (Albania), ${ }^{19}$ those who have been quarantined (Malta) ${ }^{20}$ and those without housing (Belgium). ${ }^{21}$ Moreover, militaries have taken part in sending and receiving international assistance, including in the transportation of patients, medical staff, and personal protective equipment (PPE). These military logistical and transportation activities have been uncontroversial and have not infringed the Code or other core documents.

Second, participating States have used their armed forces for medical support, including the disinfection of public areas, the manufacturing of PPE, the construction and management of field hospitals, testing, and contact tracing, the provision of military medical staff, PPE, infrastructure, and equipment, and the management of morgues. While these activities have been relatively uncontroversial, they raise concerns in relation to the Code. To begin with, they involve activities that potentially expose soldiers to the virus and that raise the issue of the human rights and fundamental freedoms of armed forces personnel, particularly regarding their health and safety at work ( $\$ 32$ of the Code). In many cases, it has been reported (usually by military unions) that soldiers did not have proper training or sufficient PPE, resulting in unnecessary infections and deaths. ${ }^{22}$ In addition, the involvement of the military in population testing and tracing raises concerns regarding potential human rights violations and civil-military tensions $(\$ 2$, $\$ 17$ of the Code). In Slovakia, for example, the armed forces implemented obligatory testing of the Roma population, which, according to Amnesty International, only added "to [the] stigmatization and prejudice they already face". ${ }^{23}$

Third, the armed forces have been used for research and development. This includes the development and testing of vaccines, disinfectants, tracing applications, and PPE. The only activity in this category identified in the present study that potentially infringes the Code $(\$ 32)$ is the testing of vaccines on Russian soldiers. ${ }^{24}$ Even though the soldiers volunteered, this is potentially problematic insofar as the military is a hierarchical structure in which pressure, either direct or indirect, can undermine informed consent. ${ }^{25}$ Other known research and development activities conducted by the militaries of OSCE participating States have been unproblematic in terms of adherence to the Code.

Fourth, participating States have used their armed forces as governance support to other bodies of government. In Lithuania, for instance, ${ }^{26}$ military experts in strategic communication provided support to the civilian authorities in curbing disinformation and fake news. ${ }^{27}$ The British Armed Forces embedded military planners in local governments to support planning and decision-making. ${ }^{28}$ In Ireland, members of the Defence Forces assisted health authorities with contact tracing. ${ }^{29}$ Planners from the Armed Forces of the Netherlands have been assigned to national crisis structures, the Ministry of Health, and other civilian institutions to support coordination. ${ }^{30}$ The support to civilian authorities provided by 
the armed forces in these and similar capacities is unproblematic as long as these forces are "under the effective control of constitutionally established authorities and subject to the rule of law" ( $\$ 36)$ and as long as they remain politically neutral as an institution $(\$ 23)$. In all of the cases known to the authors of this paper, this provision has been complied with, and no instances of military bodies making decisions that lie outside of civilian democratic control have been recorded within the observed region.

Finally, a significant number of participating States have used their militaries for internalsecurity. This includes border control, migration management, the provision of law and order, quarantine enforcement, and the protection of hospitals, retirement centres, public enterprises, and critical infrastructure. Some countries, such as Germany and the UK, have refrained from using their militaries for internal security due to constitutional constraints and historical sensitivities. ${ }^{31}$ In those states where the military has been assigned this role, the use of undue force has been reported in several participating States. In Serbia, for example, military police were mobilized to guard the asylum centres in which the country's approximately 9,000 refugees were detained throughout the state of emergency. ${ }^{32}$ In Ireland and the Netherlands, it has also been reported that asylum seekers were detained on military premises. ${ }^{33}$ The military was also deployed to protect borders in several OSCE participating States, including Greece, Croatia, Poland, the Czech Republic, Latvia, Lithuania, the Netherlands, North Macedonia, Austria, Portugal, Serbia,
Slovakia, and Slovenia. This led to the involvement of the armed forces of several participating States in migrant pushbacks and human rights violations. In Croatia, the military was involved in a violent pushback at the Croatian border, while in Slovenia paramilitary vigilantes patrolled the southern border in an attempt to prevent migrants from entering. ${ }^{34}$ In many participating States, armed forces have been deployed to safeguard quarantines, patrol the streets, and guard establishments. While such military aid to civilian authorities is acceptable in certain contexts, especially when police capacities have been exhausted, there has been no clearly expressed rationale or definition of the roles and missions of the armed forces in several such instances, which has raised concern. ${ }^{35}$ In Hungary ${ }^{36}$ and Serbia, ${ }^{37}$ extensive use of the military for internal security purposes has not always been warranted by public health considerations and has only worsened the ongoing democratic backsliding that has taken place in these countries.

\section{Conclusion and policy recommendations}

The COVID-19 pandemic caught the world by surprise. It has exposed weaknesses that have affected the ability of national governments and international organizations to coordinate their efforts to limit the spread of the virus in a timely manner and to deploy their assets proportionately, in a way that consistently upholds the human rights and fundamental freedoms of their citizens. More 
than one-third of participating States declared a state of emergency, and some applied unusually draconian, maximally restrictive lockdown measures. Across the European part of the OSCE region, countries have deployed armed forces for transportation, medical support, research and development, governance support, and the provision of internal security.

Although the use of armed forces has for the most part been warranted and uncontroversial, in some cases, especially with respect to the provision of internal security, it has not been in compliance with the OSCE Code of Conduct. The activities undertaken by armed forces in modern, developed states must be based on the rule of law and a well-established, clearly defined legal framework. Armed forces are strategic reserves and "hard power assets" that states can draw on to defend themselves legitimately against outside enemies and to provide peace enforcement and peacekeeping within the mandates given to them by the United Nations Security Council. Armed forces are therefore structurally ill-suited to tackling non-military domestic problems such as the coronavirus crisis, as illustrated by the examples of misbehaviour and overstepping of competences outlined above.

The deployment of armed forces in extraordinary situations and states of emergency, and the extent of proper parliamentarian and democratic control over such deployments, is a significant litmus test for a society's commitment to democratic standards (and the commitments of its top-level politicians). Shortcomings in the deployment of armed forces during the COVID-19 crisis are thus symptoms of underlying, deeply rooted, systemic governance issues. If these failings could merely be attributed to poor implementation, stress, and lack of experience, future insufficiencies and failures could be avoided through assessments and lessons learned processes led by political and parliamentarian representatives. If they originate in general failures of governance, however, they may be attributed to weak democratic institutions and/or democratic political culture. The coronavirus crisis may therefore serve as a useful indicator for the state and quality of democratic governance. In this context, we may also refer to $\$ 20$ of the Code, in particular to its final provision that participating States shall "[...] further the integration of their armed forces with civil society as an important expression of democracy".

Any policy recommendations must remain tentative, given the evolving situation of the coronavirus crisis. Nevertheless, analysing recent deployments of armed forces in response to the crisis against the backdrop of the norms and principles enshrined in the Code allows us to make several preliminary policy recommendations that should be taken into consideration by the OSCE and its participating States:

- Emergency measures and the use of armed forces must be conducted within states' constitutional framework and fully under democratic, parliamentary, and civilian control. OSCE participating States should implement the relevant norms and provisions of the 1990 Copenhagen Document, the 1991 Moscow Document on the Hu- 
man Dimension of Security, the 1992 concluding document of the Helsinki Summit, and the 1994 OSCE Code of Conduct on Politico-Military Aspects of Security.

- COVID-19 task forces should take the form of ad hoc government formations led by heads of governments or health ministers rather than ministries of defence. If providing military aid to civilian authorities in the context of a pandemic or other civilian task, armed forces should play a strictly subsidiary role and should be subordinated to the leading civilian authority.

- Competent and clear hierarchies and tailor-made rules of behaviour (ROB) and/or rules of engagement (ROE) are of paramount importance to ensure the efficient and constitutional deployment of armed forces in civilian environments and productive interaction between armed forces and civilians.

- Joint training and drills by all institutions and agencies dealing with emergency situations and disaster relief should be carried out regularly at the national, regional, and local levels, thus increasing the efficiency and effectiveness of their responses. These different governance levels should also develop a shared understanding of vertical interaction with a clear list of tasks assigned to each level, according to the principle of subsidiarity.

- Members of armed forces who are deployed during the pandemic should be trained and equipped to minimize contagion. Military activities that have no relevance to national security or territorial defence (ongoing conflict, defence against armed attack, etc.) or which cannot be organized in full compliance with health measures should be suspended or downscaled.

- Within the requirements of service, members of armed forces should be able to enjoy and exercise their human rights and fundamental freedoms, which include the inviolability of the individual service member's physical integrity. Service members should not be unnecessarily exposed to biological threats; if they are, they should be properly protected. Moreover, members of armed forces should not be ordered to "volunteer" in the testing of newly developed vaccines or medications, which would be a clear abuse of the military hierarchy.

- The annual exchange of information on the Code, which is considered part of the OSCE's toolbox of confidence- and security-building measures, should be more extensively used as a platform for exchanging information on how participating States are dealing with the emergency situation caused by the pandemic and how the Code's norms and provisions are being upheld. ${ }^{38}$

- The OSCE participating States, as well as the OSCE Secretariat, should step up their efforts to raise awareness of the importance of the Code. Over the past years, the OSCE's relevance has unfortunately diminished in the eyes of many participating States, and many OSCE documents are no longer well known. This means that governments may plan for the emergency de- 
ployment of troops without consulting the Code as a key norm-setting document.

- The implementation of seminars, workshops, and other activities across the OSCE region aimed at universalizing participating States' familiarity with the Code should be further encouraged and intensified. In addition, a chapter dedicated to the issue of implementing the Code in extraordinary situations/states of emergency could be included in a revised version of the Compilation of Practical Examples on the Democratic Control of Armed Forces, a best practice guide on the implementation of the Code of Conduct throughout the OSCE region. ${ }^{39}$

- Emergency measures and the challenge of their proportionate application (as illustrated by the coronavirus crisis) are not new; they reflect more general shortcomings, especially in countries with pre-existing governance challenges and deficiencies. A few participating States have already announced their intention to undergo a thorough self-evaluation regarding their COVID-19 response. Such an assessment should target the actions of all executive branches, both civilian and military, and should encompass all actors, from the top command and control level down to police and military personnel on the ground. It should be aimed at determining the extent to which these actors have complied with the principles of proportionality and of doing the least harm possible.
- ODIHR could assist participating States in conducting such assessments and self-evaluations, drawing on general concepts and experiences from past cases. Following its assessment of the situation in the OSCE region, ODIHR could provide general recommendations to all participating States through the publication of a best practice guide on parliamentary democratic control of armed forces during states of emergency and emergency situations. Furthermore, ODIHR should be given the opportunity to share the conclusions of its OSCE-wide assessment by issuing tailor-made recommendations to individual participating States, if desired.

\section{Notes}

1 The authors would like to thank the anonymous reviewers for their valuable comments on the earlier version of this manuscript.

2 OSCE, Code of Conduct on Politico-Military Aspects of Security, DOC.FSC/1/95, 3 December 1994, available at: https://w ww.osce.org/fsc/41355.

3 Prasenjit Chaudhuri, Alexandre Lambert and Thomas Schmidt (eds.),"20 Years of OSCE Code of Conduct on Politico-Military Aspects of Security", Swiss Armed Forces, June 2015 at: https://www.osce.or $\mathrm{g} /$ files/f/documents/8/4/128961.pdf.

4 OSCE, Document of the Moscow Meeting of the Conference on the Human Dimension of the CSCE, 3 October 1991, available at: https://www.osce.org/odihr/e lections/14310.

5 The Conference on Security and Co-operation in Europe (CSCE) was renamed 
the Organization for Security and Co-operation in Europe (OSCE) in 1995.

OSCE, CSCE Helsinki Document 1992:

The Challenges of Change, 9-10 July 1992, available at: https://www.osce.org $/ \mathrm{mc} / 39530$.

OSCE, Document of the Copenhagen Meeting of the Conference on the Human Dimension of the CSCE, 29 June 1990, available at: https://www.osce.org/o dihr/elections/14304.

Further international norms and provisions relevant to OSCE participating States are laid out in the International Covenant on Civil and Political Rights $(\mathbb{S} \mathbb{S} 12,17,21)$, the European Convention for the Protection of Human Rights and Fundamental Freedoms ( $\mathbb{S} 8,11)$, and $\$ 2$ of Protocol No. 4 to the European Convention.

9 OSCE, Forum for Security Co-operation, Decision No. 2/09: Technical Update on the Questionnaire on the Code of Conduct, FSC.DEC/2/09, 1 April 2009, available at: https://www.osce.org/fsc/36748.

10 See: Permanent Mission of Switzerland to the Organization for Security and Cooperation in Europe (OSCE), the United Nations and other International Organizations in Vienna, Information Exchange on the Code of Conduct on Politico-Military Aspects of Security, Note 21/2020OSCE, FSC.EMI/75/20, 15 April 2020, p. 18, available at: https://www.osce.org/file s/f/documents/8/3/450214.pdf.

11 As of the publication of the ODIHR Report: OSCE/ODIHR, OSCE Human Dimension Commitments and State Responses to the Covid-19 Pandemic, 2020, p. 20, available at: https://www.osce.org/ odihr/human-rights-states-of-emergency-c ovid19.

12 Ibid., p. 11.

13 Ibid., p. 36.

14 Ibid., pp. 64ff.
15 Eric Van Rythoven, "What's wrong with the war metaphor", Duck of Minerva, 5 April 2020, at: https://duckofminerva.co $\mathrm{m} / 2020 / 04$ /whats-wrong-with-the-war-me taphor.html.

16 Christopher Watterson and Adam Kamradt-Scott, "Fighting Flu: Securitization and the Military Role in Combating Influenza", in: Armed Forces \& Society 1/2016, pp. 145-168.

17 Hazan V. Molina et al., "The Military Role in a Flu Pandemic", Harefuah 1/2010, p. 9.

18 Katarina Đokić, "The armed forces against COVID-19 in the Western Balkans: One invisible enemy and a few visible flaws”, European Western Balkans, 5 May 2020, at: https://europeanwesternbal kans.com/2020/05/05/the-armed-forces-ag ainst-covid-19-in-the-western-balkans-one -invisible-enemy-and-a-few-visible-flaws/.

19 Republic of Albania, Armed Forces, "COVID - 19, FA vijojnë angazhimin në operacionin humanitar dhe në monitorim/patrullim në gjithë vendin”, 15 April 2020, at: https://aaf.mil.al/te-fund it/5514-covid-19-fa-vijojne-angazhimin-ne -operacionin-humanitar-dhe-ne-monitori m-patrullim-ne-gjithe-vendin.

20 "Soldiers delivering groceries to people in quarantine, CPD assisting police in spot checks", Malta Independent, 16 March 2020, at: https://www.independ ent.com.mt/articles/2020-03-16/local-new s/Soldiers-delivering-groceries-to-people-i n-quarantine-CPD-assisting-police-in-spot -checks-6736220894.

21 "CORONA - What are the Belgian Armed Forces doing in the fight against Covid-19?", March 2020, at: http://eurom il.org/wp-content/uploads/2020/03/Coro na-What-are-the-Belgian-Armed-Forces-d oing.pdf.

See for example the report by the United Association of Spanish Military, "INFORME Situación del COVID-19 en Fuerzas Armadas ¿QUIÉN PROTEJE AL 
QUE PROTEJE?”, EUROMIL, 2 April 2020, at: http://euromil.org/wp-content /uploads/2020/04/200402-Informe-AUME -prevención-COVID-19.pdf.

23 Amnesty International, "Roma must not be further stigmatized during COVID-19”, EUR 72/2110/2020, 8 April 2020, at: https://www.amnesty.org/downl oad/Documents/EUR7221102020ENGLI SH.PDF.

24 "Russia's coronavirus vaccine 'ready', military says", The Moscow Times, 21 July 2020, at: https://www.themoscowtimes .com/2020/07/21/russias-coronavirus-vacc ine-ready-military-says-a70941.

25 "Russia's coronavirus vaccine trials have a few problems”, Meduza, 5 June 2020, at: https://meduza.io/en/feature/2020/06/ 06/russia-s-coronavirus-vaccine-trials-have -a-few-key-problems.

26 Republic of Lithuania, Ministry of National Defence, "Frequently asked questions about the Lithuanian Armed Forces in the context of COVID19", 14 April 2020, at: https://kam.lt/en/news_1098/cur rent_issues/frequently_asked_questions about_the_lithuanian_armed_forces_and _covid $19 . \bar{h}$ tml.

27 "MOD team to tackle coronavirus fake news and scams", Forces, 9 April 2020, at: https://www.forces.net/news/mod-te am-tackle-coronavirus-fake-news-and-s cams.

28 Erica Pepe/Amanda Lapo, “Europe's armed forces and the fight against COVID-19”, IISS, 9 April 2020, at: https:/ /www.iiss.org/blogs/military-balance/202 0/04/europe-armed-forces-covid-19.

29 "80 Defence Forces cadets are being trained in Covid-19 contact tracing", The Journal, 13 March 2020, at: https://www. thejournal.ie/defence-forces-cadets-traine d-in-coronavirus-contact-tracing-5046020 -Mar2020/.

30 Government of the Netherlands, Ministry of Defence, "Deployment of the
Netherlands Ministry of Defence in the Fight against COVID-19, 11 March-1 July", at: https://english.defensie.nl/topics/c orona-covid-19.

31 Pepe and Lapo, cited above (Note 28).

32 Nikola Kovačević, Deprivation of liberty of refugees, asylum seekers and migrants in the Republic of Serbia through measures of restriction and measures of derogation from human and minority rights made under the auspices of the state of emergency, A 11 - Initiative for Economic and Social Rights, 16 March 2020, at: https://www.a11initiative.org/wp-content /uploads/2020/05/Deprivation-of-liberty-o f-refugees.pdf.

33 Mark Akkerman, "COVID-19 and Border Politics”, Border Wars Briefing 1, Transnational Institute/Stop Wapenhandel, July 2020, at: https://www.tni.org/fil es/publication-downloads/tni-covid-19-an d-border-politics-brief.pdf.

34 Dušan Stojanović, "Vigilantes in Slovenia patrol borders to keep out migrants", AP, 17 September 2019, at: https://apnews.co $\mathrm{m} / 57424 \mathrm{e} 6 \mathrm{bf} 60046 \mathrm{e} 594 \mathrm{~b} 4 \mathrm{c052bac86b6c.}$

35 Akkerman, cited above (Note 33).

36 BIRN, “Hungarian 'militarisation' under Orban stirs concern”, Reporting Democracy, 29 July 2020, at: https://balkaninsig ht.com/2020/07/29/hungarian-militarisati on-under-orban-stirs-concern/.

37 Filip Ejdus, "Pandemijske lekcije za politiku i system odbrane Republike Srbije”, MONS, 7 May 2020, at: http://mons.rs/pa ndemijske-lekcije-za-politiku-i-sistem-odb rane-republike-srbije.

38 See also Note 10 above.

39 Annual discussion on the implementation of the Code of Conduct on politicomilitary aspects of security, Consolidated Report, FSC.GAL/96/14, 24 July 2014. at: http://www.osce.org/fsc/121796. 
